\title{
INDEKS EKOLOGI GASTROPODA SEBAGAI BIOINDIKATOR PENCEMARAN AIR DI EKOWISATA SITU BAGENDIT KECAMATAN BANYURESMI KABUPATEN GARUT
}

\author{
Sriwahjuningsih $^{1}$, Hudi Hernawan ${ }^{2}$, dan Nurul Fitri ${ }^{3}$ \\ ${ }^{1,2,3}$ Program Studi Pendidikan Biologi Fakultas Ilmu Terapan dan Sains, Institut Pendidikan Indonesia \\ Jl. Terusan Pahlawan No. 12 Sukagalih Tarogong Kidul, Garut \\ Emai: ningsriwahjuningsih@gmail.co.id
}

\begin{abstract}
Abstrak: Beberapa aktivitas masyarakat disekitar perairan situ secara langsung maupun tidak langsung dapat berdampak terhadap kualitas perairan sungai diantaranya dapat mempengaruhi faktor-faktor biotik dan abiotik yang mengakibatkan rusaknya ekosistem di perairan. Penelitian bertujuan untuk mengetahui indeks ekologi gastropoda sebagai bioindikator pencemaran air yang terdapat di Ekowisa Situ Bagendit pada bulan April - Juni 2021. Metode penelitian yang digunakan adalah deskriptif dengan pendekatan kualitatif, metode pengumpulan data dan metode penentuan stasiun dengan purposive sampling method terhadap 10 stasiun. Sampel yang diambil meliputi pengukuran parameter biotik (gastropoda) serta abiotik. Hasil pengukuran parameter biotik penelitian menunjukkan famili dari tiga stasiun berjumlah 5 famili diantaranya famili Thiaridae, famili Ampullariidae, famili Viviparidae, Lymnaeidae dan Famili Littorinidae, dan terdiri dari 16 spesies dengan total 1495 individu. Rata-rata nilai indeks keanekaragaman adalah 1,6860 termasuk kategori sedang, kenekaragaman tertinggi adalah spesies Melanoides formensis $(0,3570)$ dan terendah adalah, spesies Thiara rufis $(0,0044)$. Rata-rata nilai indeks kelimpahan adalah, 100,6091 termasuk kategori sangat banyak, nilai kelimpahan tertinggi pada spesies Melanoides formosensis $(28,2274)$ dan terendah pada spesies Thiara rufis $(0,01)$. Rata-rata nilai indeks dominansi adalah, 0,1852 termasuk kategori rendah nilai dominansi tertinggi pada spesies Melanoides formosensis $(0,0796)$ dominansi terendah pada spesies Thiara rufis (0). Rata-rata nilai indeks kemerataan adalah, 28,5078 termasuk kategori stabil, nilai kemerataan tertinggi pada spesies Pomaceae maculata $(3,5338)$ dan Lymnea Rubiginosa $(3,5338)$ terendah pada spesies Thiara rufis $(0)$. Rata-rata nilai indeks kepadatan adalah, 149,5 termasuk kategori tinggi, nilai kepadatan tertinggi pada spesies Melanoides formenssis $(42,2)$ terendah pada spesies Thiara rufis $(0,1)$.
\end{abstract}

Kata Kunci : Gastropoda, indeks ekologi

Abstract: Several community activities around the lake waters can directly or indirectly affect the quality of river waters, including influencing biotic and abiotic factors that cause damage to ecosystems in the waters. The purpose of this study was to determine the ecological index of gastropods as a bioindicator of water pollution in Ekowisa Situ Bagendit in April - June 2021. The research method used was descriptive with a qualitative approach, data collection methods and station determination methods with purposive sampling method on 10 station. The samples taken included measurements of biotic (gastropod) and abiotic parameters. The results of the measurement of the biotic parameters of the study showed that there were 5 families from three stations including the Thiaridae family, Ampullariidae family, Viviparidae family, Lymnaeidae and Littorinidae family, and consisted of 16 species with a total of 1495 individuals. The average diversity index value is 1.6860 including the medium category, the highest diversity is Melanoides formensis species (0.3570) and the lowest is, Thiara rufis species (0.0044). The average abundance index value is 100.6091, including the very large category, the highest abundance value is Melanoides formosensis (28.2274) and the lowest is Thiara rufis (0.01). The average dominance index value was 0.1852 , including the low category, the highest dominance value was in the Melanoides formosensis species (0.0796), the lowest dominance was in the Thiara rufis species (0). The average evenness index value was 28.5078 , including the stable category, the highest evenness value was in the Pomaceae maculata species (3.5338) and Lymnea Rubiginosa (3.5338) the lowest was in the Thiara rufis species (0). The average density index value is 149.5, including the high category, the highest density value is in Melanoides formenssis species (42.2) and the lowest is in Thiara rufis species (0.1).

Keywords: Gastropods, ecological index 
Jurnal Cahaya Mandalika, Vol. 3, No. 1, 2022 ,e- ISSN: 2721-4796

Available online at: http://ojs.cahayamandalika.com/index.php/JCM

Copyright @ 2021 Publisher: Institut Penelitian \& Pengembangan Mandalika Indonesia

\section{PENDAHULUAN}

Situ Bagendit adalah salah satu situ alami yang sumber airnya berasal dari curah hujan, saluran pembuang daerah irigasi Ciojar dan saluran pembuang Cibuyutan selatan, serta saluran keluar air situ Bagendit melalui Parigi. Situ Bagendit dimanfaatkan oleh warga sekitar sebagai sarana pariwisata dan sebagai mata pencaharian dalam bidang perikanan, seperti kegiatan penangkapan ikan, pembesaran ikan di karamba jaring apung, dan sebagai irigasi bagi areal pesawahan (Amelia 2016 dalam Iqbal, 2019).

Kondisi kualitas perairan di bumi selalu berubah-ubah dalam segi kualitas ataupun kuantitas, hal ini salah satunya dipengaruhi aktivitas makhluk hidup, manusia memanfaatkan air untuk berbagai keperluan sehari-hari untuk mandi, mencuci, memasak air, industri dan lain-lain. Kegiatan-kegiatan tersebut apabila tidak dikelola dengan benar dan bijak akan menyebabkan dampak negatif terhadap sumberdaya air, salah satunya dapat menurunkan kualitas air. Kondisi perairan sungai secara tidak langsung dapat menunjukkan kondisi lingkungan (Wibowo, 2012 dalam Devita, 2017).

Organisme yang hidup di perairan seperti makrozoobenthos sangat peka terhadap perubahan kualitas air tempat hidupnya sehingga akan berpengaruh terhadap komposisi dan kelimpahannya. Hal ini tergantung pada toleransinya terhadap perubahan lingkungan, sehingga organisme ini sering dipakai sebagai indikator tingkat pencemaran suatu perairan (Mason, 1993 dalam Mushtofa dkk, 2014).

Gastropoda merupakan biota air yang umumnya tidak dapat bergerak cepat dan mudah terpengaruh oleh adanya bahan pencemar kimiawi serta keberadaan lumpur, pasir dan arus air. Pada perairan yang belum tercemar sebaran organisme gastropoda ini relatif merata begitu juga sebaliknya pada perairan yang sudah tercemar akan ada spesies yang mendominasi. Perubahan substrat dan penambahan bahan pencemar akan berpengaruh terhadap kepadatan, komposisi dan tingkat keragaman zoobenthos (Fauziah et. al. 2010 dalam Yuli dkk, 2017).

\section{METODE PENELITIAN}

Metode pengambilan sampel yang digunakan adalah dengan metode deskriptif (kuantitatif) purposive sampling, Penelitian ini dilakukan dengan metode transek kuadrat, pengambilan sampel dilakukan dengan dua kali pengulangan pada setiap lokasinya. Daerah stasiun yang diteliti yaitu 10\% dari luas Situ Bagendit atau sekitar 60 meter dari luasan Situ bagendit $\pm 0,6 \mathrm{~km}$.

\section{Waktu dan Tempat Penelitian}

Penelitian dilakukan pada bulan April - Juni 2021. Penelitian dilakukan di Ekowisata Situ Bagendit Kecamatan Banyuresmi Kabupaten Garut, Dinas Lingkungan Hidup Garut dan Laboratorium Biologi Institut Pendidikan Indonesia. 


\section{Populasi dan Sampel Penelitian}

Populasi yang diteliti dalam penelitian ini adalah seluruh spesies Gastropoda yang berada dan hidup di perairan Ekowisata Situ Bagendit Kecamatan Banyuresmi Kabupaten Garut. Sampel yang diambil dari penelitian ini adalah seluruh spesies Gastropoda yang tercuplik pada daerah pencuplikan di perairan Ekowisata Situ Bagendit Kecamatan Banyuresmi Kabupaten Garut

\section{Teknik Pengambilan Sampel}

Pengambilan sampel gastropoda pada setiap stasiun dilakukan di zona profundal yaitu merupakan bagian dasar air yang tidak tercapai oleh penetrasi cahaya yang efektif. Stasiun yang diamati berjumlah tiga dan masing-masing stasiun dilakukan pemasangan satu garis transek yang bertujuan untuk mengukur jarak sebaran gastropoda. Panjang garis transek adalah $10 \%$ dari panjang situ yaitu 60 meter, pada setiap transek dipasang sejumlah plot secara berseling. Pada setiap stasiun terdiri dari 10 plot masing-masing plot mempunyai ukuran 1 meter x 1 meter. Pada setiap transek dilakukan pengulangan sebanyak 2 kali sehingga jumlah plot pada seluruh stasiun yaitu 60 plot atau 60 pencuplikan. Panjang setiap garis transek stasiun yaitu 20 meter dengan jarak antar stasiun yaitu 50 meter. Pengambilan sampel dilakukan pada pagi-sore hari (Iqbal, 2019).

Pengukuran faktor fisika dan kimia dilakukan pada pagi-sore hari adapun faktor fisika yang diamati diantaranya, adalah suhu, kelembapan, intensitas cahaya, kecepatan angin, kecerahan air dan kedalaman sedangkan faktor kimia yang diamati diantaranya, adalah $\mathrm{Ph}$ air, oksigen terlarut (DO), Biologichal Oxygen Demand (BOD) dan Chemical Oxygen Demand (COD).

\section{Alat dan Bahan Penelitian}

Bahan yang digunakan dalam penelitian ini adalah formalin $4 \%$ dan aquadest. Adapun, alat yang digunakan dalam penelitian ini, adalah alat tulis, buku identifikasi gastropoda, alat pengukur gastropoda, transek $(1 \mathrm{mx} 1 \mathrm{~m})$, ember, toples, tissue, kertas label, GPS, thermometer, pHmeter, hygrometer, luxmeter, anemometer, spektometer uv-vis, pipet tetes, tabung erlenmeyer, buret, kamera.

\section{ANALISIS DATA}

Data yang diperoleh dianalisis nilai indeks ekologi dengan menghitung nilai indeks keanekaragaman, kelimpahan, dominansi, kerapatan dan kemerataan.

\section{Indeks Keanekaragaman}

Untuk mengetahui indeks keanekaragaman gastropoda dapat dihitung dengan menggunakan rumus Shannon-Wienner dalam Soegianto (1994), yaitu:

Keterangan :

$$
H^{\prime}=-\sum \frac{n i}{N} \operatorname{In} \frac{n i}{N}
$$

$\mathrm{H}^{\prime}=$ indeks diversitas (keanekaragaman) Shannon-Wiener 
$\mathrm{ni}=$ jumlah setiap jenis ke-i

$\mathrm{N}=$ jumlah total (keseluruhan) individu

\section{Indeks Kelimpahan}

Untuk melihat kelimpahan data yang diperoleh, digunakan rumus kelimpahan sebagai acuan yang sesuai nomor urut kunci determinasi dengan menggunakan rumus Kelimpahan Michael (1994 dalam Hasanah, 2016).

Keterangan :

$$
K=\frac{\sum \text { individu suatu spesies }}{\sum \text { individu seluruh spesies }} \times 100 \%
$$

$\mathrm{K}=$ Nilai Kelimpahan

\section{Indeks Dominansi}

Indeks Dominansi dihitung dengan rumus Dominance of Simpson (Odum, 1971).

$$
D=\Sigma\left[\frac{n i}{N}\right]^{2}
$$

Dimana :

$\mathrm{D}=$ Indeks dominansi

$\mathrm{ni}=$ Jumlah Individu setiap jenis

$\mathrm{N}=$ Jumlah total individu

\section{Indeks Kemerataan}

Kemerataan dapat dihitung dengan menggunakan rumus indeks equibilitas menurut Evennes (1996 dalam Odum, 1998) sebagai berikut:

Keterangan :

$$
E \frac{\bar{H}}{\log S}
$$

$\mathrm{E}=$ Nilai Kemerataan

$\bar{H}=$ Indeks keanekaragaman Shannon-Whienner

$\log S \quad=$ Jumlah Individu

\section{Indeks Kepadatan}

Kepadatan $(\bar{x})$ menurut Odum (1993) sebagai berikut:

Keterangan :

$$
\bar{x}=\frac{\sum X n}{n}
$$

$X n=$ Jumlah individu spesies

$n=$ Jumlah plot/sampling

\section{HASIL DAN PEMBAHASAN}

Tabel 4.1 menunjukkan jumlah Gastropoda yang ditemukan dari tiga stasiun berjumlah 5 famili diantaranya famili Thiaridae, famili Ampullariidae, famili Viviparidae, Lymnaeidae dan Famili Littorinidae, dan 16 spesies diantaranya, Melanoides tuberculata, Melanoides formosensis, Melanoides plicaria, Melanoides torulosa, Stenomelania clavus, Tarebia lineata, Tarebia granifera, Pomaceae maculata, Pomacea insularum, Pomacea canaliculata, Pomacea sp, Lymnea rubiginosa, Thiara rufis, Bellamya javanica, Filopaludina javanica, dan Littorina sp. Jumlah individu 
yang ditemukan sebanyak 1495 individu, dari hasil rekapitulasi tiga stasiun didapatkan spesies yang paling tinggi adalah Melanoides formosensis dengan jumlah 422 individu dan spesies yang paling rendah adalah Thiara rufis dengan jumlah 1 individu.

Tabel 4.1 Rekapitulasi Spesies Gastropoda pada Tiga Stasiun Pencuplikan (Jumlah Individu)

\begin{tabular}{|l|l|c|c|c|c|}
\hline \multirow{2}{*}{ No } & \multirow{2}{*}{ Nama Spesies } & \multicolumn{3}{|c|}{ Stasiun } & \multirow{2}{*}{$\begin{array}{c}\text { Jumlah } \\
\text { Individu }\end{array}$} \\
\cline { 3 - 5 } & & I & II & III & 258 \\
\hline 1. & Melanoides tuberculata & 105 & 104 & 49 & 422 \\
\hline 2. & Melanoides formosensis & 81 & 133 & 81 & 112 \\
\hline 3. & Melanoides plicaria & 70 & 27 & 15 & 92 \\
\hline 4. & Melanoides torulosa & 77 & 14 & 1 & 18 \\
\hline 5. & Stenomelania clavus & 15 & 3 & 0 & 233 \\
\hline 6. & Tarebia lineata & 138 & 83 & 12 & 304 \\
\hline 7. & Tarebia granifera & 140 & 102 & 62 & 3 \\
\hline 8. & Pomaceae maculata & 2 & 1 & 0 & 8 \\
\hline 9. & Pomacea insularum & 5 & 2 & 1 & 4 \\
\hline 10. & Pomacea canaliculata & 4 & 0 & 0 & 3 \\
\hline 11. & Pomacea sp & 2 & 2 & 0 & 1 \\
\hline 12. & Lymnea rubiginosa & 3 & 0 & 0 & 3 \\
\hline 13. & Thiara rufis & 1 & 0 & 0 & 3 \\
\hline 14. & Bellamya javanica & 2 & 1 & 0 & $\mathbf{1 4 9 5}$ \\
\hline 15. & Filopaludina javanica & 9 & 14 & 4 & \\
\hline 16. & Littorina sp & 3 & 0 & 0 & \\
\hline Jumlah & $\mathbf{7 8 4}$ & $\mathbf{4 8 6}$ & $\mathbf{2 2 5}$ & \\
\hline
\end{tabular}

Spesies Gastropoda yang Tercuplik dan Teridentifikasi pada Zona Profundal Ekowisata Situ Bagendit Kecamatan Sukaratu Kabupaten Garut

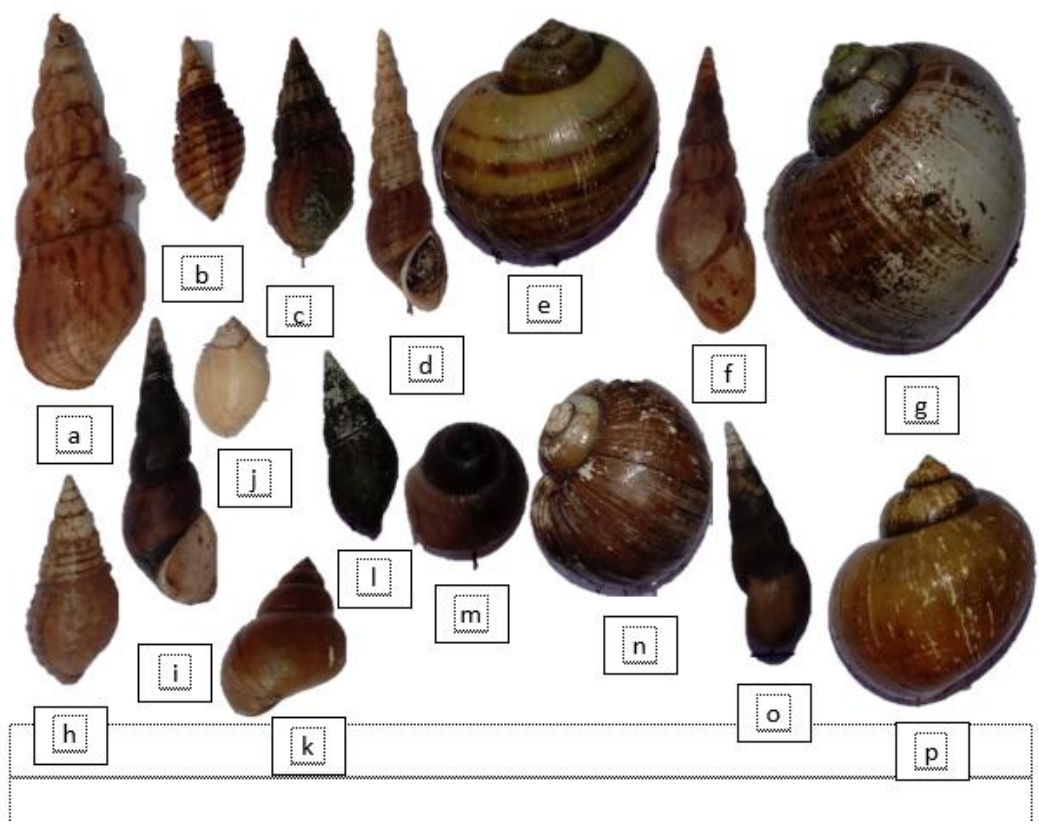

Spesies yang Ditemukan Di Ekowisata Situ Bagendit a : Melanoides tuberculata, b : Tarebia granifera, $\mathrm{c}$

: Thiara rufis, d : Stenomelania clavus, e : Pomaceae canaliculata, f : Melanoides formosensi, g :

Pomacea insularum, $\mathrm{h}:$ Tarebia lineata, $\mathrm{i}:$ Melanoides plicaria, $\mathrm{j}:$ Lymnea rubiginosa, $\mathrm{k}:$ Filopaludina javanica, $1:$ Littorina sp, $\mathrm{m}:$ Bellamya javanica, $\mathrm{n}:$ Pomacea maculata, o : Melanoides torulosa, $\mathrm{p}$ :

Pomacea sp 


\section{Nilai Indeks Ekologi Gastropoda}

\section{Indeks Keanekaragaman}

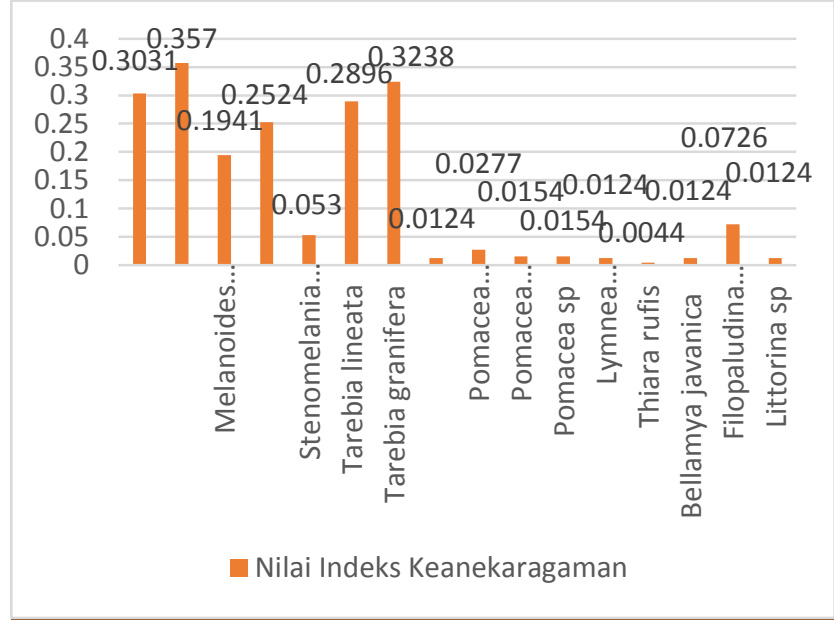

\section{Gambar 2}

Diagram Nilai Indeks Keanekaragaman Spesies Gastropoda yang Terambil pada Tiga Stasiun

Rata-rata nilai indeks keanekaragaman adalah, 1,6860 termasuk kategori sedang. Nilai keanekaragaman tertinggi terdapat pada spesies Melanoides formensis dengan nilai indeks keanekaragaman 0,3570. Tingginya nilai indeks keanekaragaman tersebut dipengaruhi oleh beberapa faktor diantaranya yaitu faktor parameter fisika, kimia serta keadaan ekologi. Hal ini sesuai dengan Ratna (2012) habitat Melanoides formosensis umumnya mengubur pada substrat dan dasar perairan serta selalu bersifat menetap, kondisi lingkungan seperti tipe sedimen, kedalaman, kecerahan, suhu, $\mathrm{pH}$ perairan memberikan variasi yang besar pada kehidupan gastropoda.

Nilai indeks keanekaragaman terendah terdapat pada spesies Thiara rufis dengan nilai indeks 0,0044. Hal tersebut karena spesies ini merupakan spesies yang paling sedikit ditemukan di lokasi penelitian karena kondisi habitat di situ bagendit kurang mendukung bagi kelangsungan hidup spesies tersebut.

\section{Indeks Kelimpahan}

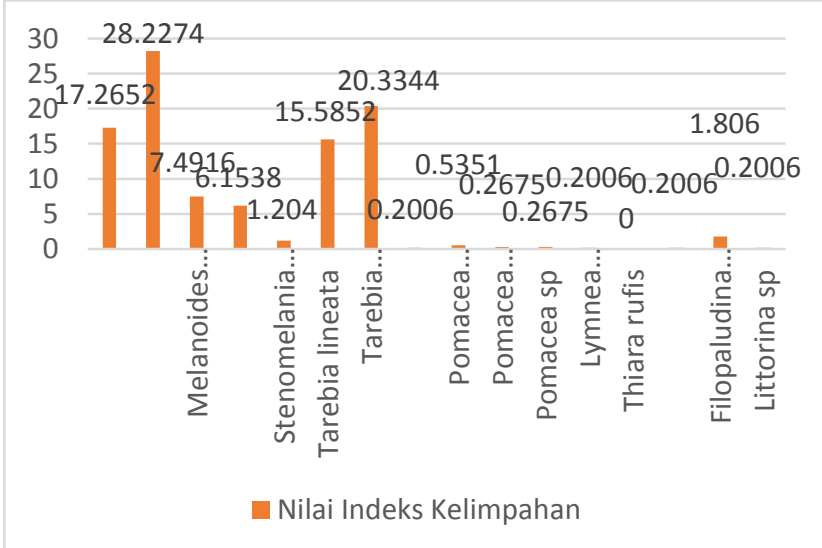

Gambar 3 
Diagram Nilai Indeks Kelimpahan Spesies Gastropoda yang Terambil pada Tiga Stasiun

Rata-rata nilai indeks kelimpahan yaitu, 100,6091 termasuk kategori sangat banyak. Nilai indeks kelimpahan tertinggi terdapat pada spesies Melanoides formensis dengan nilai indeks kelimpahan 28,2274 sedangkan nilai indeks terendah terdapat pada spesies Lymnea rubiginosa dengan nilai indeks kelimpahan 0,2006. Hal ini sesuai dengan pendapat (Karyono, dkk, 2013) yang menyatakan bahwa Gastropoda jenis Melanoides formensis merupakan organisme perairan yang tenang serta bagian dasar yang berlumpur, sehingga pada siput ini sampai semua habitat dapat dihuninya.

Sedikitnya jenis Thiara rufis di jumpai Ekowisata Situ Bagendit ini memiliki substrat yang berlumpur dan bersifat tidak menetap. Hal ini sesuai dengan pendapat (Djajasasmitha, 1999) yang menyatakan bahwa Gastropoda jenis Thiara rufis merupakan organisme yang menyukai perairan yang tenang serta memiliki substrat belumpur dan berbatu.

\section{Indeks Dominansi}

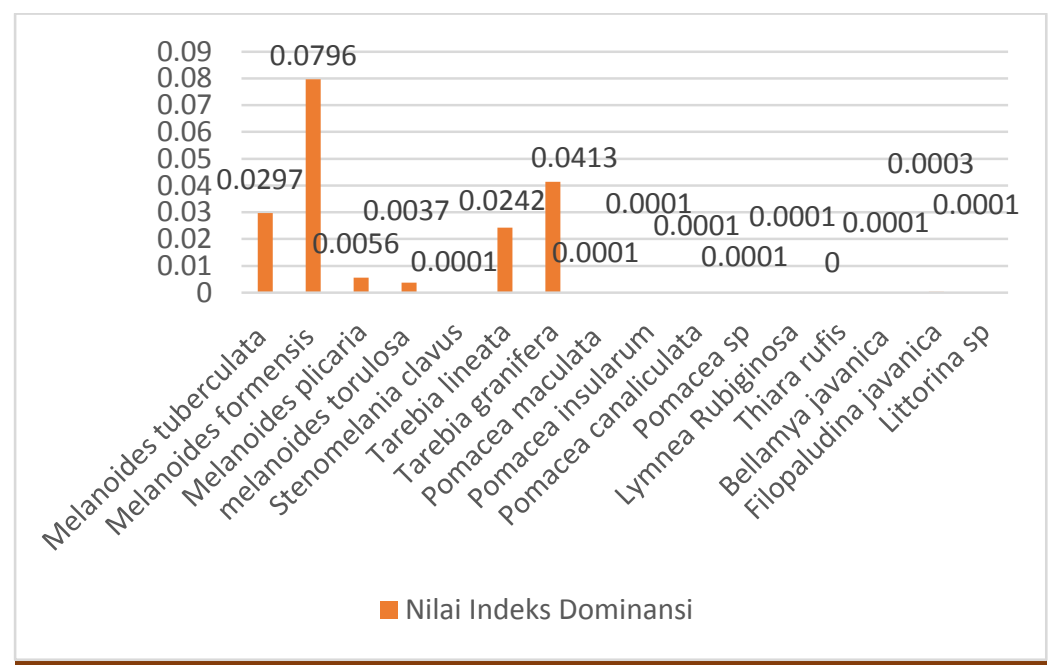

Gambar 4

Diagram Nilai Indeks Dominansi Spesies Gastropoda yang Terambil pada Tiga Stasiun

Hasil perhitungan data diperoleh nilai dominansi tertinggi pada spesies Melanoides formensis dengan nilai 0,0796 dan nilai terendah terdapat pada spesies Thiara rufis dengan nilai 0 . Rata-rata nilai indeks dominansi 0,1852 yang didapatkan mendekati 0, maka didalam struktur komunitas Gastropoda yang di amati tidak terdapat spesies yang mendominasi spesies lain. Hal ini menunjukkan bahwa kondisi struktur komunitas Gastropoda di Ekowisata Situ Bagendit dalam keadaan stabil.

Hal ini sesuai dengan pendapat (Oktavianti et. all., 2014) berpendapat bahwa apabila indeks dominansi pada suatu komunitas mendekati 0 maka tidak ada spesies yang mendominasi spesies lain hal tersebut menunjukkan bahwa kondisi struktur komunitas dalam keadaan stabil. 


\section{Indeks Kemerataan}

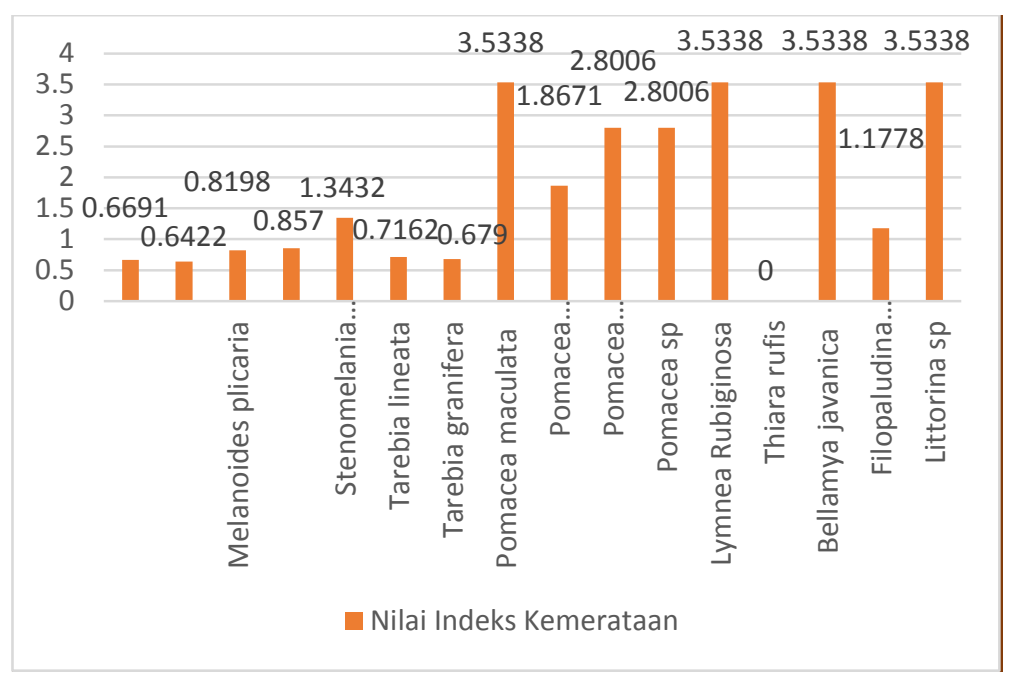

\section{Gambar 5}

Diagram Nilai Indeks Kemerataan Spesies Gastropoda yang Terambil pada Tiga Stasiun

Rata-rata nilai indeks kemerataan yaitu, 28,5078 termasuk kategori stabil. Nilai indeks kemerataan tertinggi terdapat pada spesies Pomacea maculata, Lymnea rubiginosa, Littorina sp dan Belamya javanica dengan nilai indeks kemerataan 3,5338 sedangkan nilai terendah terdapat pada spesies Thiara rufis dengan nilai indeks kemerataan 0 .

Tingginya nilai indeks pada spesies Pomacea maculata, Lymnea rubiginosa, Littorina sp dan Belamya javanica dengan nilai 3,5338 dimana nilai indeks kemerataan mendekati 1 maka dapat dikatakan bahwa komunitas Gastropoda di Ekowisata Situ Bagendit dalam keadaan stabil, hal tersebut terjadi karena seimbangnya ekosistem yang ada di Ekowisata Situ Bagendit.

Rendahnya nilai indeks kemerataan pada spesies Thiara rufis dengan nilai indeks kemerataan 0 diduga disebabkan karena spesies tersebut tidak dapat menyeimbangkan dengan keadaan ekosistem yang ada di Ekowisata Situ Bagendit. Hal tersebut sesuai dengan pendapat (Djajasasmitha, 1999) yang menyatakan bahwa Gastropoda jenis Thiara rufis merupakan organisme yang menyukai substrat berbatu. 


\section{Indeks Kepadatan}

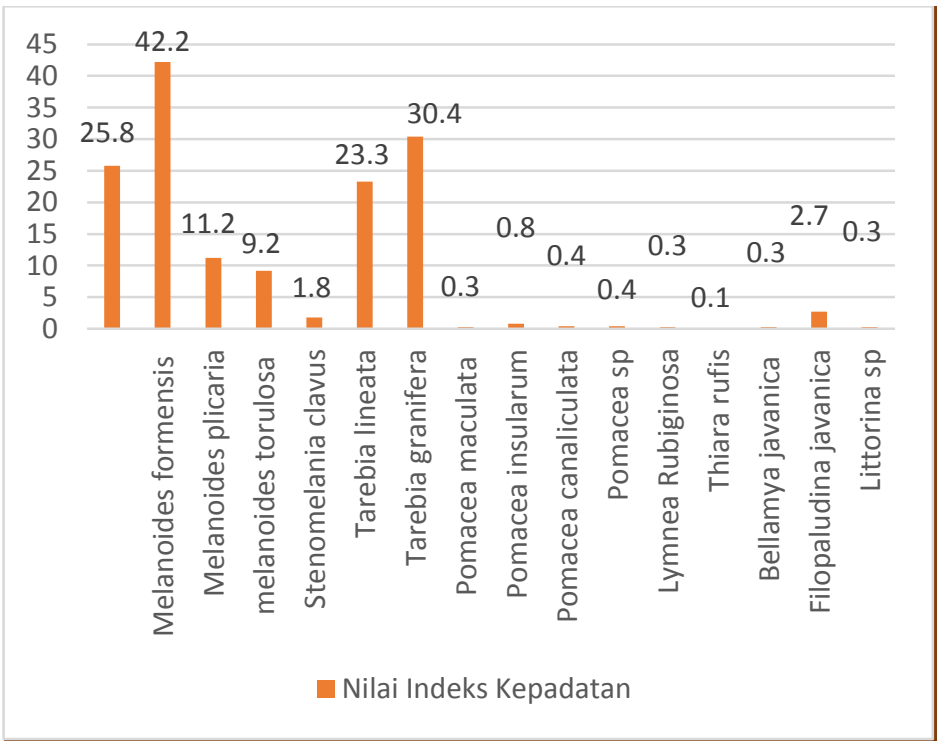

Gambar 6

Diagram Nilai Indeks Kepadatan Spesies Gastropoda yang Terambil pada Tiga Stasiun

Rata-rata nilai indeks kepadatan 149,5 terasuk kategori tinggi . Nilai indeks kepadatan berhubungan dengan tingkat keanekaragaman suatu komunitas. Berdasarkan hasil penelitian didapatkan bahwa nilai indeks yang tinggi pada spesies Melanoides formensis denga nilai indeks kepadatan 42,2 yang memiliki tingkat kepadatan tinggi pada spesies tersebut, sedangkan nilai terendah terdapat pada spesies Thiara rudis dengan nilai indeks kepadatan 0,1. Hal tersebut sesuai dengan pendapat (Odum, 1993) menyatakan bahwa kepadatan jenis adalah sifat suatu komunitas yang menggambarkan tingkat keanekaragaman jenis suatu komunitas tersebut.

\section{Parameter Fisika}

Faktor lingkungan fisika merupakan salah satu faktor yang menentukan kelangsungan makhluk hidup di suatu perairan. Rata-rata suhu air di tempat penelitian berkisar antara $25^{\circ} \mathrm{C}-30^{\circ} \mathrm{C}$, kisaran suhu pada ketiga stasiun ini masih dapat ditolelir oleh organisme khusunya Gastropoda. Batasan toleransi tertinggi untuk keseimbangan struktur populasi hewan Gastropoda pada suhu mendekati $32^{\circ} \mathrm{C}$, tetapi beberapa jenis dapat mentolelir suhu yang lebih tinggi. Rata-rata kelembaban di ketiga stasiun yaitu berkisar antar 50\% - 70\%, kelembaban udara tidak berpengaruh secara langsung pada kehidupan hewan di suatu perairan.

. Intensitas cahaya berkisar antara 150,58x100 lux - 310,60x100 lux, pada lokasi penelitian kondisi airnya masih bersih sehingga cahaya dapat menembus kedasar perairan sesuai dengan kedalaman ketiga stasiun tersebut. Rata-rata kecapatan angin berkisar antara $67-75 \mathrm{~m} / \mathrm{s}$. Kecerahan air pada ketiga stasiun berkisar antara 50,5 cm $85 \mathrm{~cm}$. Kecerahan air pada suatu perairan berperan penting karena dapat mengakibatkan terganggunya sistem osmoregulasi, misalnya pernafasan, dan daya lihat organisme akuatik serta dapat menghambat penetrasi cahaya ke dalam air (Mushtofa et. al., 2014). 
Kedalaman berkisar antara 2,3 m - 3,5 m. Menurut Mushtofa (2014) kedalaman suatu perairan, berhubungan terhadap kelimpahan organisme, dimana peningkatan kedalaman air diikuti dengan penurunan kelimpahan organisme, sebaliknya kelimpahan suatu organisme lebih tinggi diperairan yang dangkal.

\section{Parameter Kimia}

Hasil pengukuran derajat keasaman atau kebasaan $(\mathrm{pH})$ pada ketiga lokasi yaitu berkisar antara 8,20 - 8, 35. Kisaran ini berada dalam nilai yang diperbolehkan dalam baku mutu air situ kelas I, II dan III. Nilai DO (Dissolved Oxygen) pada ketiga lokasi tersebut berbeda-beda yaitu berkisar antara 7,31 mg/l - 8,22 mg/l. Nilai rata- rata DO pada ketiga stasiun tersebut adalah 7,27 mg/l. Berdasarkan PP Nomor 28 tahun 2001 menyatakan bahwa kisaran DO yang diperuntukkan bagi kehidupan Gastropoda adalah 3-4 (mg/l), semakin besar DO pada suatu perairan maka sangat mendukung bagi kehidupan suatu organisme perairan.

Nilai rata-rata BOD (Biological Oxygen Demand) pada ketiga lokasi penelitian yaitu 3,65 mg/l. Kisaran ini berada dalam nilai yang melebihi dalam baku mutu air kelas II yaitu melebihi $3 \mathrm{mg} / \mathrm{l}$ (Santoso. A, 2018). Nilai rata-rata COD (Cemichal Oxygen Demand) pada ketiga stasiun berkisar antara $24,80 \mathrm{ppm}$. Kisaran ini berada dalam nilai yang diperbolehkan baku mutu air sungai kelas II. Dari hasil penelitian diperoleh rata-rata BOD dan COD menunjukkan termasuk kedalam kelas II.

\section{KESIMPULAN}

a. Indeks Keanekaragaman

Nilai indeks keanekaragaman tertinggi adalah spesies Melanoides formensis $(0,3570)$ dan nilai indeks keanekaragaman terendah adalah spesies Thiara rufis $(0,0044)$ dengan rata-rata nilai keanekaragaman, yaitu 1,6860 termasuk kategpri sedang.

b. Indeks Kelimpahan

Nilai tertinggi terdapat pada famili Thiaridae pada spesies Melanoides formosensis $(28,2274)$ dan nilai indeks kelimpahan terendah terdapat pada famili Lymnaeidae pada spesies Lymnaea rubiginosa $(0,2006)$ dengan rata-rata nilai kelimpahan, yaitu 100,691 termasuk kategori sangat banyak.

c. Indeks Dominansi

Nilai tertinggi terdapat pada famili Thiaridae pada spesies Melanoides formosensis $(0,0796)$ dan indeks dominansi terendah terdapat pada famili Thiaridae pada spesies Thiara rufis (0) dengan rata-rata nilai dominansi, yaitu 0,1852 termasuk kategori rendah.

d. Indeks Kemerataam

Nilai tertinggi terdapat pada spesies Pomacea maculata, Lymnea rubiginosa, Bellamya javanica dan Littorina sp $(3,5338)$ dan nilai indeks kemerataan terendah terdapat pada famili Thiaridae pada spesies Thiara rufis (0) dengan rata-rata nilai kemerataan, yaitu 28,5078 termasuk kategori stabil.

e. Indeks Kepadatan 
Nilai tertinggi terdapat pada famili Thiaridae pada spesies Melanoides formosensis $(42,2)$ dan nilai indeks kepadatan terendah terdapat pada famili Thiaridae pada spesies Thiara rufis $(0,1)$ dengan rata-rata nilai kepadtan, yaitu 149,5 termasuk kategori tinggi.

\section{DAFTAR PUSTAKA}

Amelia, C. D, Hasan Z., \& Mulyani, Y. (2012). Distribusi Spasial Komunitas Plankton sebagai Bioindikator Kualitas Perairan di Situ Bagendit Kecamatan Banyuresmi, Kabupaten Garut, Provinsi Jawa Barat. Jurnal Perikanan dan Kelautan. 3(4): 301-311.

Dharma, B. 1988. Siput Dan Kerang Indonesia. PT. Sarana Graha, Jakarta.

Djajasasmita, M. 1999. Keong dan Kerang Sawah. Puslitbang Biologi LIPI, Bogor. 57 Hal.

Devita, N. (2017). Analisis Pencemaran Air Dengan Gastropoda Sebagai Bioindikato Di Aliran Sungai Sumur Putri Teluk Betung Bandar Lampung.

Fauziah, Y., E, Febrita, Dan S, Alayubi. 2010. Struktur Komunitas BivalvIa Di Perairan Sungai Siur Kanan Kecamatan Tebing Tiggi Barat Kabupaten Kepulauan Meranti. Program Studi Pendidikan Biologi Jurusan Pmipa Fkip. Universitas Riau. Pekanbaru.

Mason, J. 1993. Dasar-dasar Ekologi. Edisi Ketiga. Diterjemahkan oleh Eidman dan Bangen. P.T. Gramedia. Jakarta.

Mushtofa Aqil, Rudiyanti Siti, Rudolf Muskananfola Max. 2014. Analisis struktur komunitas makrozoobenthos sebagai bioindikator kualitas perairan sungai wedung kabupaten Demak. Diponogoro Journal of Maquares, Vol 3 no 1.

Odum, E.P. (1996). Dasar-dasar ekologi. Terjemahan oleh Ir. Tjahyono Samingan, MSc dan Ir. B. Srigandono, Msc.Yogyakarta: Gajah Mada University Press.

Peraturan Menteri Lingkungan Hidup Indonesia No 5 Tahun 2014 tentang Baku Mutu Air Limbah

Soegianto, A. 2010. Ekologi Perairan Tawar. Surabaya: Pusat Penerbitan dan Percetakan (AUP).

Wibowo Haryo. 2012. Identifikasi jenis, kerapatan dan diversitas plankton bentos sebagai bioindikator perairan sungai pepe surakarta. Jurnal Bioedukasi. Vol 5 No 2.

Yuli, Y., El Fajri, Dan Fauzi, M. (2017). Kelimpahan Gastropoda Di Sungai Kampar Kanan Kelurahan Air Tiris Kecamatan Kampar. 